\title{
How many fingers should be there to be a competent electrician?-two cases of ectrodactyly
}

\author{
Chandrasekharan Rajasekharan, Thomas Nishanth \\ Department of Internal Medicine, Medical College Hospital, Thiruvananthapuram, Kerala, India
}

Correspondence to Professor Chandrasekharan Rajasekharan, drcrajasekharan@yahoo.com

\section{DESCRIPTION}

Two patients, a 74-year-old electrician and a 54-year-old male plumber were admitted for cardiac disease. Both the patients reported no disability in doing their job effectively. Both patients improved with treatment. The first patient was having bilateral ectrodactly with partial involvement of the feet, showing aplastic index middle and hypoplastic ring finger on the right side and absent ring finger on the left side (bilateral Lobster-claw deformity). The third toe is absent on the left foot (figure 1A). The second patient presented with hypoplasia on the left index middle and ring finger with sparing of the toes. In both these patients, there was no evidence of any other congenital malformations (figure 1B). Ectrodactyly-ectoderm dysplasia-clefting syndrome (EEC) is an example of ectrodactyly syndrome accompanied by multiple organ defects. Ectrodactyly, also known as split-hand/split-foot malformation (SHFM) is a rare genetic condition characterised by defects of the central elements of the autopod. It has a prevalence of
1:10 000-1:90 000 worldwide. The EEC syndrome is an $\mathrm{X}$ linked and autosomal dominant disorder with variable expressivity and reduced penetrance. ${ }^{1}$

\section{Learning points}

A patient with isolated ectrodactyly can live near normal life except for the social stigma which constitutes to major challenges to survival of such patients.

- It is important to screen patients for ocular manifestations as progressive visual impairment may be the most disabling feature of the syndrome. ${ }^{2}$

Acknowledgements To both of my patients

Competing interests None.

Patient consent Obtained

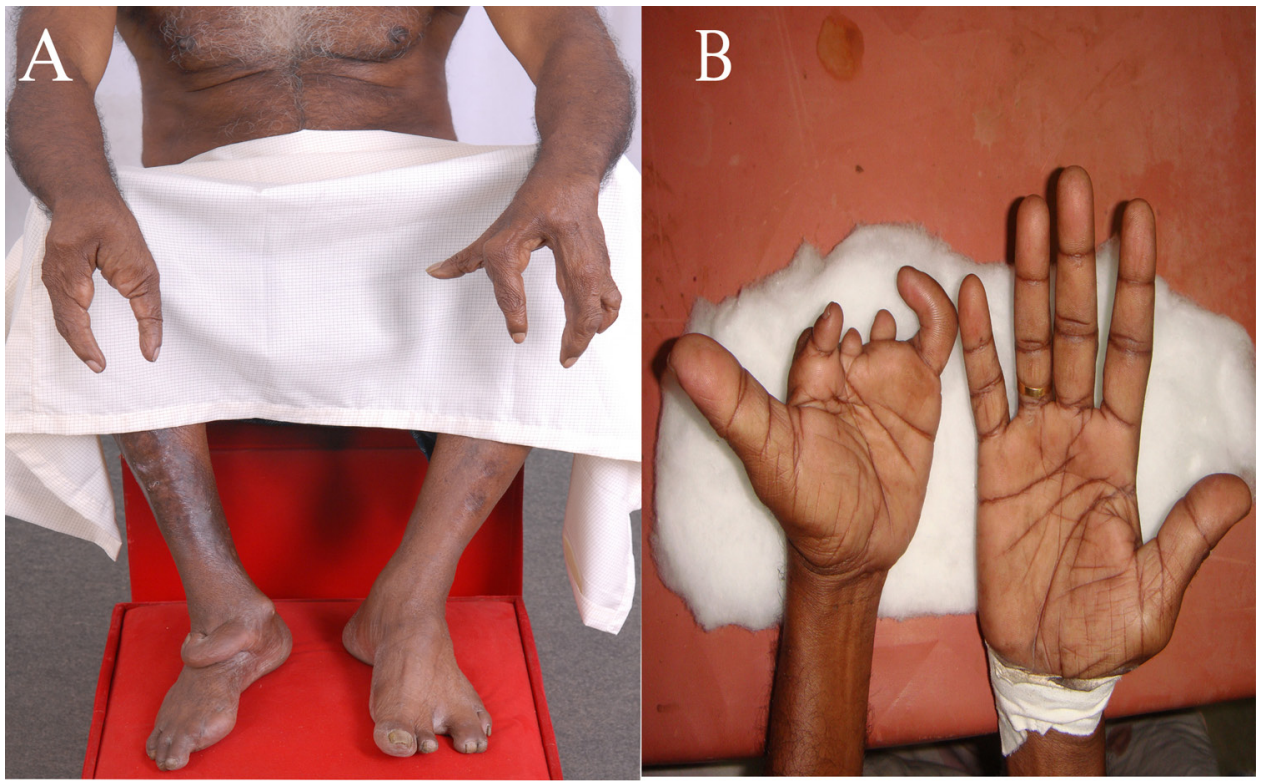

Figure 1 (A) The first patient was having bilateral ectrodactly with partial involvement of the feet, showing aplastic index middle and hypoplastic ring finger on the right side and absent ring finger on the left side (bilateral Lobster hand deformity). The third toe is absent on the left foot (patient showing aplastic index middle and hypoplastic ring finger on the right side and absent ring finger on the left side). The third toe is absent on the left feet. (B) The second patient had hypoplasia on the left index middle and ring finger with sparing of the toes. In both these patients there was no evidenceof any other congenital malformations. 


\section{BMJ Case Reports}

\section{REFERENCES}

1. Penchaszadeh VB, de Negrotti TC. Ectrodactyly-ectodermal dysplasiaclefting (EEC) syndrome: dominant inheritance and variable expression. J Med Genet 1976;13:281-4.
2. McNab AA, Potts MJ, Welham RA. The EEC syndrome and its ocular manifestations. Br J Ophthalmol 1989;73:261-4.

This pdf has been created automatically from the final edited text and images.

Copyright 2012 BMJ Publishing Group. All rights reserved. For permission to reuse any of this content visit http://group.bmj.com/group/rights-licensing/permissions.

BMJ Case Report Fellows may re-use this article for personal use and teaching without any further permission.

Please cite this article as follows (you will need to access the article online to obtain the date of publication).

Rajasekharan C, Nishanth T. How many fingers should be there to be a competent electrician?-two cases of ectrodactyly. BMJ Case Reports 2012;10.1136/bcr.03.2012.6149, Published XXX

Become a Fellow of BMJ Case Reports today and you can:

- Submit as many cases as you like

- Enjoy fast sympathetic peer review and rapid publication of accepted articles

- Access all the published articles

- Re-use any of the published material for personal use and teaching without further permission

For information on Institutional Fellowships contact consortiasales@bmjgroup.com

Visit casereports.bmj.com for more articles like this and to become a Fellow

Keep up to date with all published cases by signing up for an alert (all we need is your email address) http://casereports.bmj.com/cgi/alerts/etoc 